\title{
Books on Ethics as Instructive Texts and an Unknown Copy of Ahmed Mürşidî Efendi's Book on Ethics
}

\author{
Müzahir Kiliç \\ Turkish Education Department, Faculty of Education, Agri Ibrahim Cecen University, Turkey
}

Copyright $(2017$ by authors, all rights reserved. Authors agree that this article remains permanently open access under the terms of the Creative Commons Attribution License 4.0 International License

\begin{abstract}
Suggestion or admonition means advice. In literature, works which give advices on religion, communal living, occupations and management services or show the way to be a good person and be successful in life are called advice letters (pend-nâme). Advice letters are advice books. They are the rules that mark out how to be a good person in society and direct the human life in the direction of the commands and prohibitions of İslam. These rules have been formed in accordance with the İslamic commands, and to an extent they are the prohibitions to be obeyed. It is seen that such works have been written in almost every era of classical Turkish literature. Kutadgu Bilig, Atabetü'l-Hakâyık and Divan-1 Lügati't-Türk as the first works of Islamic literature are like advice books in terms of the subjects and messages they carry. Even Göktürk inscriptions are like an advice book with its messages that represent a historical experience. Two significant works of this field are the books on ethics written by Güvahi and Ahmed Mürşidî Efendi. These works are particular source for linguistic area as they include mottos along with proverbs, idioms, anecdotes and fairy tales. The works of Ahmed Mürşidî Efendi known as poet of books on ethics have many written and printed copies. A written copy of this work was explored by one of our students. This copy which consists of 201 sheets and 7265 couplets was copied by Muhammed Nuri Efendi from Burdur. An artisan in Burdur keeps it.
\end{abstract}

Keywords Classical Turkish Literature, Book on Ethics, Advice Letter, Ahmed MÜRşidî Efendi, Written Copy

\section{A. Instructive Texts}

There exists a suggestive style in Orkhun Inscriptions, the initial writings of Turkish literature and in Kutadgu Bilig which belongs to the later ages and is one of the first Islamic-Turkish writings, it is narrated how to be an emperor. In Divan-1 Lügat-it-Türk, Kaşgarlı Mahmut gives advice by using the proverbs, as well. Yüknekli Edib Ahmet's Atabetü'l-Hakayık is another sample which examples the situations with hadiths and the verses from Quran. The continuation of this tradition was provided with Yunus
Emre's Risâletü'n-Nushiyye and Mevlana's Masnavi, combined with suggestions and advises uttered for the sake of completing the man's superior virtues. [1] 791-2

\section{A.1. Books on Ethics as Instructive Texts}

The word "pend" having the meaning of suggestion and advice in Persian bears the meaning books on ethics, suggestion leaflet or advisory booklet with the word "name" together. Aiming at leading the readers mature morally and socially and providing mature people for the society, these books on ethics are of the didactic works [2]. It is an inevitable fact that Islamic and religious works bears the feature of being instructive at first. Many issues related with lives and religions are dealt with in this work. Many issues such as possessions, parental right over the child, family, partners, halal, haram, government, faith and generosity, goodness, infidelity, slander, arrogance, pledge, belief, desire, chant in Quran, longing, smoking, mahatmas' oracle, science of cifr, alchemy, the prophet, Muhammad's passion are given place in this work. Besides its instructiveness, the work is known as "book on ethics" as it gives advice.

In classical Turkish literature, a lot of books on ethics and advisory books have been written down. Attar's books on ethics have been patterned and many good works are laid out via translation and copyright. There are 43 advisory books, some of which were republished and 110 books on ethics even in the records of the National Library. By the virtue of matter, books and papers in this field have been written in Turkish literature and again papers have been represented in academic symposiums and congress. I hold the opinion that a little information about would be better in terms of understanding, emphasising and comprehending matters.

\section{Instructive Texts before Islam}

\subsection{Orkhun Inscriptions}

The most significant art works of this era is written in stones, Orkhun Inscriptions. As an afterward situational assessment between Turks and Chinese, the work is the written form of Bilge Khan's advices and suggestions for his children. Significant messages are given in these writings as 
follows with its Turkish translation.

1. (Ben) Tanrı gibi, Tanrıdan olmuş Türk Bilge Hakan. $\mathrm{Bu}$ devirde( tahta) oturdum. Sözlerimi baştan sonaişitin. Önce, (siz) erkek kardeşlerim (ve) oğullarım, birleşik boyum (ve) halkım, sağdaki Şadapit beyler, soldaki Tarkanlar (ve) kumandan beyler, Otuz Tatar...

2. Dokuz Oğuz beyleri (ve) halkı, bu sözlerimi iyice işitin (ve) sıkıca dinleyin: İleri(de) gün doğusuna, güneyde gün ortasına kadar, geride gün batısına (ve) kuzeyde gece ortasına kadar, bu (sınırlar) içindeki bütün halklar hep bana tabidir. Bunca halkı hep

3. düzene soktum. Onlar şimdi (hiç de) kötü (durumda) değiller. Türk (lerin) kağanı Ötüken dağlarında oturur (ordan hükmeder) ise ülkede (hiçbir) sıkıntı olmaz. Doğuda Şantung ovasına kadar ordu sevk ettim, denize pek az kala durdum, güneyde Dokuz Ersin'e kadar ordu sevk ettim, Tibet'e pek az kala durdum. Batıda İnci (Sır Derya) ırmağı(nı)

4. geçerek Demir Kapı 'ya kadar ordu sevk ettim. Kuzeyde Yir Bayırku topraklarına kadar ordu sevk ettim. Bunca diyara kadar (ordularımı) yürüttüm. (ve anladım ki) Ötüken dağlarından daha iyi bir yer asla yok imiş.(Türk halkının yurt edineceği ve ) yönetileceği yer Ötüken dağları imiş. Bu yerde yerleşip Çin halkı ile

5. (ilişkileri) düzelttim. . (Çinliler) altın(1), gümüş(ü), ipeğ(i) ve ipekli kumaşları güçlük çıkarmaksızın öylece (bize) veriyorlar. Çin halkının sözleri tatlı, ipek kumaşları (da) yumuşak imiş. Tatlı sözlerle (ve) yumuşak ipekli kumaşlarla kandırıp uzak (larda yaşayan) halkları böylece (kendilerine) yaklaştırırlar imiş. (Bu halklar) yaklaşıp yerleştikten sonra (da Çinliler) fesatlıklarını o zaman düşünürler imiş. [3]

Its translation in English:

1. (Me) I am from the God, Turk Bilge Khan, like God. I got the crown at that age. Listen to me from top to toe. Firstly, (you) my brothers (and) sons, tribe (and) people, at the right Şadapits and on the left Tarkans (and) commanders, 30 Tatars...

2. 9 Oghuz leaders (and) their peoples are all ears and listen to me carefully: at front till the east, the South (and) at behind till the West and at the North till the midnight everything (all the people) belongs to me. I reign all over these peoples.

3. They are rather good. The khan of Turks reins them from Ötüken Mountains and there would be no troubles in their home. I assigned armies till the Şantung plain, I got till the seas, in the south I prompted the armies till 9 Ersin, I stopped a little before Tibet.

4. I walked my army on the lands till Demir Kap1 passing by the River Inci (Sir Derya) and to the Yir Bayırku on the North. I walked my army all over these lands I said. Finally, I got that no place is better than the Mountains Ötüken. It was the Mountains Ötüken from where Turks would be governed and they would settle. After settling here.

5. I improved the relations with China. China gives the gold, silver and the silk without any objections. Their words were sweet and silk was soft. They made anyone living far away get closer themselves with sweet words and soft silk. After these people settling and getting nearby, they would think sedition afterwards.

Having the feature of being a speech as well, Orkhun Inscriptions (Göktürk inscriptions, obelisks, Bengü steles are of great importance in terms of Turkish history and culture. It advises the nation to keep its morals and values unspoilt; it is reviewed that because of the leaders and people admiration for Chinese, the state is collapsed and the nation is taken under chain. However, it is stated that they can manage to found out an independent state when they act in unity steles [4]. It is advised not to be fooled by Chinese women, silk and their good words but to be in unity. Splitting up and division has the same meaning with being easy meat. Today we live the same things even more. In the case of not having lessons from the past, it is giving information about the sake of the empires. The utterance 'Turkish people, behave yourself and come to your sense' is not for nothing.

The monuments that were erected for Tonyukuk (724,726), Kültigin (732) and Bilge Khan are historical monuments of Turkish nation as well.

\section{Instructive Texts after Islam}

With the acceptance of Islam, the rules and morals of the new religion were integrated in literary works. Regarded as the initial literary works, Kutadgu Bilig, Atabetü'l Hakâyık nad Divan-1 Hikmet of Hodja Ahmet Yesevi are the works including religious rules and ethics.

\subsection{Kutadgu Bilig}

I have no doubt that Kutadgu Bilig - a significant mirror of Turkish nation and its history of thought as well- can be utilized a lot in terms of increasing new joints about the information of being Turkish [5] VIII Evaluation of this work today is of great importance. Written by Yusuf Has Hacib, this literary work is actually a book of government. Within the light of religious and moral values, the emperor, Küntoğdu, stands for the judgement, his vizier Aytoldu for fortune, the vizier's son Ögdülmüş for wisdom and the vizier's brother Odgurmuş for fate. Evaluated in a catechetical way, the sections involve the rules and forms of politeness besides the morals and rules of governing. In many parts of the work, instructive texts that is subtitled as "it is advised that..." take part in. The couplets between the numbers 6521-6645 in the work give information about the badness of time, longing for youth and self-advisory parts 
that Yusuf Has Hacip prepared for himself. Examples from these couplets and their translations in English are given below in Turkish:

6451. Ey âlim, bugünkü zamana dikkat et işler tamamen değişti. (Dervish, you, take your guard against the time, it changed a lot)

6452 Bilgili hakir oldu, bir tarafa sinip kalıyor; akıllı dilsiz oldu, ağzını açmıyor. Şarap ile yüzlerini yıkayan, ibadeti bırakanlar şimdi yiğit sayılıyor ve istediklerini yapıyorlar. (no respect to the one in wisdom, cringing on his side; wise became dummy, can't open his mouth. The ones swimming in wine, giving up pray are now ranked among heroes and well, then, have power to make it they desire.

6467 Halktan vefa gitti, cefa çoğaldı; itimat edilecek bir kimse ararsan, bulamazsin. (no loyality in man, but cruelty mostly; bay the moon rather seeking for a trust man, .)

6481 Müslümanlar karışt1, birbirlerinin etlerini yiyorlar; kâfirler ise tam bir huzur içinde yaşıorlar. (muslims got confused, they are at it hammer and tongs; but heretics are in peace)

6496 Aklımın erdiği sözlerin hepsini yazdım, ey okuyan ve anlayan insan bundan hisse al. (I penned what I was able to comprehend; now you, the reader and learner, take your steak.)

6514 Miskten ancak misk kokusu gelir; fena koku murdar şeyden çıar. (musk smells only musk, the bad smell comes from the filth)

6575 İnsanın ismi kaldı, insanlık kayboldu; bu insanlık nereye gitti, ben de arkasından gideyim. [6] 470-2

(just the name of the humanity, but itself vanished, let me tag along after it)

Written approximately 10 century ago, this art of work gives advice for the young by figuring out the themes such as disloyalty, badness of time, dishonouring for Wiseman, wisdom and so on.

\subsection{Atabetü'l-Hakâyık}

As understood from different titles, it is a book of ethics reprinted in narrative from of Turkish besides having been prepared for the nurture of individuals in the framework of Turkish-Islamic cultural world [7]. It is clearly that this literary work figures out similar titles as in Kutadgu Bilig. Complaint from time and youth and dishonouring for the wisdom comes forth among the titles that it figured out. Samples are given below in Turkish with their translation in parenthesis:

89. Kemik için ilik ne ise, insan için bilgi odur. (what is marrow for bone is the knowledge for man)

109. Bilgisize doğru söz tatsız gelir. (true word doesn't taste well to illiterate)

110. Ona öğüt ve nasihat faydasızdır. (he is bullet-proof against advice and suggestion)

127. Bilgi, malı olmayan için tükenmez bir hazinedir. (knowledge is a fortune not ending for the one not having possessions)

131. Dilini muhafaza altında tut, dişin kırılmasın. (guard your tongue, you keep your teeth healthy)

132. Çok gevezelik eden dil, karşı konulmaz bir düşmandır. (tongue in tittle-tattle is your best enemy)

169. Sirrını iyi sakla kimse bilmesin. (keep your secret, let no one know it)

170. Sözünden kendine pişmanlık gelmesin. (don't let your word reign over you)

197. Dünya malı bu gün var, yarın yoktur. (wealth is here for today, what about next)

198. benim dediğin mal başkalarının kısmetidir. (the wealth that you know yours is one's fortune)

\subsection{Divan-ı Hikmet: Ahmet Yesevî}

The age, which is worth to be studied in order to comprehend the national spirit and pleasure from the Turkish literature after the acceptance of Islam, is the one in which great Sufis made remarkable impressions with their works for centuries and managed to reach large masses [8]. Ahmet Yesevî and his work named as "Divan-1 Hikmet" have a significant place for our cult and literature.

The word "Hikmet" is used in the meaning of our prophet's sermons and guidance. Described in a variety of different meanings by a number of Islamic wise men, the meaning of the word takes part in the dictionaries as follows: glorious characteristics created by the combination of science and justice, the existence of competency and realities and the motto related with tradition and ethics...[9]. The relation of 'mysterious wisdom' with the tradition and ethics makes itself bear the feature of religious guidance. For this reason, it is seen that the guiding messages exists in most of the 'mysterious wisdoms'. The full texts of Divan-1 Hikmet are available in Kazan prints. It is claimed that Ahmet Yesevi uttered 4400 mysterious wisdoms. Their content involves the fundamentals of Islam, the provisions of sharia, teaching the doctrines and norms of followers' sunnah to the ones who have accepted Islam newly or haven't accepted yet [10] 36 Being so far from the opinion of owing the artistic characteristics can be taken as normal for they bear the didactic characteristics. These mysterious wisdoms are national in terms of style, but religious in terms of content. In some of them, suggestions are given on social troubles of both the environment and the era. Yesevi wrote his mysterious wisdoms in the nature of inviting and informing about both the prohibitions and orders of sharia and the rules and conventions of the sect that he founded under his name. One way of teaching the rules of religion is the mysterious wisdom (hikmet).

Some samples (with their simplified forms in Turkish):

Nerde görsen gönlü kırık merhem ol sen

Öyle mazlum yolda kalsa hem-dem ol sen

Mahşer günü dergâhına mahrem ol sen

Ben-sen diyen kimselerden geçtim işte

Ümmet olsan, gariplere tabi ol sen

Ayet, hadis her kim dese, sâmi ol sen

Rizık nasip her ne verse kani ol sen 
Kani olup şevk-i şarabın içtim işte (Hikmet: 1)

İnsan odur, fakir olup yolda yatsa

Toprak gibi âlem halkı basıp geçse

Yusuf gibi kardeşi köle diye satsa

Kulun kulu o kul ne diye gururlansın. (Hikmet 16)

\subsection{Güvâhi: Book of Ethics (1 $8^{\text {th }}$ century $\left.933 / 1526\right)$}

Gülvahi, which can be called as advisory book, gives place social words, proverbs and idioms mostly and figures them in the form of narrative story within the style of masnavi and aruz prosody.

Samed Alizade made a comparison upon the works related with proverbs published in Turkey and claimed that 220 of 475 proverbs that are used in Güvâhi. The book of ethics, are commonly used.

The titles of the stories that are in the style of masnavi in the book of ethics are as follows:

1. The disadvantages of not obeying to the statesmen

2. The judges' being tended on pleasure and entertainment and the harms that can come from these to their jobs.

3. The statesmen abusing and being kind not to get complaints from the uppers.

4. The judges' bribing and the public complaints.

5. As the consequence of bearing a grunge against to statesmen, harming oneself.

6. The legality of killing harmful livings in order not to damage anyone.

7. The right of everyone even the worst ones to have a value with the dignity of being a man.

8. The messengers' oppression to the people and the public complaints.

9. The harms of insatiability and greed to man.

10. The benefits of being abstinent.

11. The legitimacy of making the enemy ineffective and tricking them.

12. Patriotism.

13. The significance of making fame.

14. The significance of one's making job himself/herself (the wolf's having thick nape is from the fact that he makes his job himself.)

15. The benefits of working and the hams of laziness (as like the proverb 'rolling stone gathers no moss')

16. The failure of incompetents every time and everywhere.

17. Sibling love.

18. Illiterateness of Turks ( attributed toYörüks)

19. Turkish hospitability and fraternity.

20. Judges' complaints of the statesmen.

21. The insincerity of hodjas, not walking the talk.

22. All his geese are swans.

23. The benefits of growing up good-natured and intelligent boy.

24. The harms of growing up bad-natured boy.
25. The worry of a newly-marrying girl and types of good girls.

26. Wilderness of man not knowing love.

27. Lovers' seeing everything more beautiful than everyone (love is blind).

28. The distress of marriage, the advantages and disadvantages of good and bad man.

29. The disadvantages of marrying to widows, the advantages of marrying to young women and virgins.

30. The importance of having good and trusty mate. The necessity of keeping away from bad mate.

31. The bad effects of uttering bad words.

32. Being hunt with his own weapons.

33. The benefits of uttering good words.

34. The bad effects of uttering bad words.

35. The bad effects of saying one's mistakes without looking his own ones.

36. The advantageous of generosity.

37. Wearing plainly and beautifully.

38. Good deeds and virtues hospitability.

39. Good deed of feeding the poor.

40. The fact of no one can change the orders of Allah...[8]

\subsection{Hayriye-i Nâbi (end of $17^{\text {th }}$ century)}

Hayriye-i Nâbi comes forth among the instructive texts written in Anatolia. This art of work was written by Nâbi by targeting his 7 year-old son and the young in adolescence. This art of work whose writer -Nâbi- known as a poet of contemplation and philosophy in Divan literature, is one of the significant works that was written in its field. It is such a valuable art work that it had so much fame and value to be discussed and it even caused some disagreements in the council of poets such as "Nâbi's work named as Hayrabad had been praised and no art of work like it would be written any longer".

"One of the known samples in the field of didactic, mental and moral masnavi of Divan literature, Hayriyye Nâbi found itself a common reading area almost in all corners of Ottoman Empire". [12]

Some couplets in original form;

Kimsenin cevr ile canın sıkma

Hatırın yapmağa sa'y it yıkma

Hardan ol bî-hûda-gû bedterdür

Anı tasdik eden andan hardur.

Sen kubul eyle bu pendi benden

Dostluk var iken olma düşmen

\subsection{Sünbülzâde Vehbi Lutfiyye (Wording date 1205/1791)}

It is an 1181-couplet masnavi written in advisory form. It was probably written as a birthday gift when Lütfullah got the age 24. "Thinking that father's advice would lead lifelong, Vehbi decides to write an advisory book for his 
son" [13] during the wording of the work, it was benefitted mostly. The work consists of 91 titles. It involves suggestions dealing with a number of issues related with social life.

\section{Respect to Master (Original Version in Old Turkic) Hocaya Saygı}

Hâcene eyle be-gâyet ta'zîm

Hakk-1 üstâd aceb emr-i azîm

Harf-i pür nükte-i "men alleme"ni

Anladur kıldığııı benden seni

Kayd-1 mihnetden olur âzâde

Dâimâ kulluk iden üstâde

Hâceye her kim iderse âzâr

Görmedik olduğun berhurdâr

Tâlibe hayr-1 duâ-yı üstâd

Dü cihânda sebeb-i meyl-i murâd

\section{Handwritten form of Ahmed Mürşidi Efendi's Book of Ethics}

Name of the book: Hazâ Kitâb-1 Mürşidî Pend-i Ahmedî Rahmetullahi Aleyh

Author: Ahmed Mürşidî Efendi [14]

Sh: 1 b-210a, there exists a 12-couplet poem in 1a. From the beginning, 200 sheets are unscathed but the last 10 sheets are apart from the whole text, a full copy.

Copyist: كاتب الحروف علي العلوي لنكوموي من تلاميز Muhammed Nuri Efendi

Print date: $1286 / 1870-71$

Number of couplet: 7235

Volume: Gusseted, Head banded, brown leathered, partly worn-out, 180x115 / 177x251. Light yellow sheet, red labelled rulers, bald, the tittles are written in red ink.

Sample from original version:

Târih olsun bendine ya Ahmedî

Rahmetiyle bul cinânı sermedi 1159/1746 (wording date)

Handwritten form is in the shelf of a crafter from Burdur...

The prologue of the book consists of 61 subtitles involving various issues under the title of Hazâ fihrist-i mürşidi pend-i Ahmedî; the first subtitle bears the name of Pend-nâme ahval-ı mebhas-l fakr

\subsection{Handwritten Forms of the Work Apart from This}

3.1.1 Kitâb-1 Mürşidî Pend-i Ahmediyye, registered with the name of Alemdar Ali İbn-i Muhammed. Copyist: Hafiza Zekiye, copied in 1271, Public Library of Kastamonu Province, Registration Number 37 Hk 3976281 sht, 17 line, written in naskh form
3.1.2 Ahmed Mürşid Diyarbekrî ve Pend-i Ahmediyye, İstanbul Uni. Handwritten forms were copied by Şemsettin er-Rıfkı using Arabic calligraphy in 1282. It is in the size of $23.3 \times 16.6$ and covered in black leather, 15 lines, and 306 sheets.

3.1.3 Amidli Ahmedi ve Kitab-1 Mürşid, Süleymaniye Library, Handwrittens of Hacı Mahmud Efendi, no: 3543?2, copy date 1300, 32 pages 13 lines, outstanding copy

3.1.4 Kitab-1 Mürşid-i Pend-i Ahmediyye, copy date 1277 , handwritten collections of national library, registration number: 06 Mil Yz. B 688, 326 sheets, 15 lines, full text.

3.1.5 Kitab-1 Pend-i Ahmedî, copyist and copy date is unknown, handwritten collections of national library, registration number is 06 Mil Yz A 6162?2

3.1.6 Pend-i Ahmedi, Copyist: Hasan B .Mustafa, copied in 1250 Public Library of Zeytinoğlu District Registration Number: 43 ze 239, 191 yak,

3.1.7 Mermutlu, M.Sait (Haz), Pendnâme, Diyarbekirli Ahmed Mürşidî, Büyüyen Ay Publications, İstanbul 2012 [15]

\subsection{Diyarbekirli Ahmed Mürşidî Efendi}

Being one of the scholars in $18^{\text {th }}$ century, he is the son of Osman Ağa. Presumably, he was born in 1688/89 in the district of Yenikap1, Diyarbakır. He was orphan since his parents were dead when he was a child. After completing his education in various sciences, he took part in Sheikh Birecikli Ebubekir from Nakşıendi fellows. Afterwards, he went to make a pilgrimage and situated settled in Ali Pınarı village -a horary away from Diyarbakır- on his return. He died in 1760/6.

His works: Book of ethics, Yusuf'u Züleyha, Mevlid-i Şerif

The characteristics of his works: The work begins with the matter of poverty. It consists of matters such as namaz (prayer), parental right over the child, honor, richness, greed, commendation, haram, governing, guest, betrayal, generosity, toleration, confederacy, gossiping, self-praising and reflexion, jealousy, pride, arrogance, penitence, wedding, invocation, sins, praying, gratitude, levels of desire, reading Quran, longing, tear, invocation, divine love, weed, prophet love, mahatma oracle, science of cifr, alchemy, sorcery, praise of ummah, dervishes, death, grave, world, doomsday, the great confusion, libra, shopping, tricking, zakat (obligatory alms) neighbourhood, adultery, orphan possessions, heavenly women.

\subsection{Other Books of Ethics}

Type of Book: Attâr, known with the name of Ebu Hamid Feridüddin Attar Muhammed b. İbrahim Nisaburi. It serves as a model for most of the works written in this form. It is in the top list of samples in advisory book type that he was named as pendname (book of ethics). In almost all 
bookstores, this book can be found. The initial copies can commonly be seen in copy and translation forms. It is possible to face with the various types of prints of this work in the libraries including the handwritten form of the work in Turkey. Since it includes religious and moral issues and figures these topics in poetical style, it has been read and loved mostly. In our literature, so many books were written in the name of book of ethics and advisory book. Güvâhi's advisory book, Nâbi's Hayriyye, Sünbülzâde Vehbi's Lutfiyye are among the unique masnavis. With the name of advisory book, Pendnâme comes to the title and the name of Güvâhi's work [16]. From $14^{\text {th }}$ century to $19^{\text {th }}$ century, many books on ethics were written. Some of them were listed below.

\section{$14^{\text {th }}$ and $15^{\text {th }}$ century}

Ahmet Fakih, book of ethics; Aydınlı Müridî, Pend-i ricâl; Refîi, advisory book; Sinan Paşa, instructive book; Gülşeni-i Saruhanî, Dilgüşâ; Şeyh Eşref book of ethics.

\section{$16^{\text {th }}$ century}

Yakup Bey, Advice for sinners; Derviş Şemseddin, Dehmurg; Shah İsmail, Advisory book; Gülşehri, book of ethics; Güvâhi book of ethics; Hızrî, Adam's ale,; Muhyî, Şâhi's book of ethics; Askerî book of ethics; Zaifî Pir Mehmed, Bâğ-1 Behişt; Behişti Ramazan Efendi, Heşt Behişt; Cemâli, Risâle-i Durub-i Emsâl; Șemsittin Sivasî, Gülşen-âbâd; Ali Mustafa Efendi, Nasihatü's-Selâtin; Veysî' advisory booklet, Koçi Bey's leaflet

\section{$17^{\text {th }}$ century}

The most significant art of work is Nâbi's Hayriye. Sâfi Mustafa Efendi's, Gülșen-i Pend; Treasurer Sarı Mehmed Pasha's Nesâyihü'l-vüzerâ ve'l-umerâ; Seyyid Mehmed Emrullah Emîrî, Emirî Book of Ethics; Akhisarlı Vassâf Abdullah Efendi; Hayâl-1 Behcet-âbâd; Nîmüddin Tımışvârî; Silk-i Cevâhir; Sünbülzâde Vehbi, Lutfiyye.

\section{$18^{\text {th }}$ century}

In this era, no significant works apart from the one named 'Erzurumlu Mehmed Șerifî's Pend-i Gülistân-1 Şerifi' could be written. In republic period, Ali Fuat Başgil's work titled with 'Gençlerle Başbaşa' was penned for this purpose [17] 410

\section{Conclusions}

The art of works titled with book of ethics or advisory book have a significant place in teaching the religious rules in literal field, wide-spreading of social rules between the individuals and arranging the social life. Human being needs to learn the truth at first in order to fulfil the duty of teaching, live decently, and teach how to live so. Books of ethics duly performed their duties. These works of art have run the instructive duty in terms of teaching how to be perfect human and good person for years and the society needs these masterpieces so much today. ${ }^{1}$

\section{REFERENCES}

[1] Kaplan M, Türk edebiyatında manzum nasihatnâmeler, Yeni Türkiye publications, Ankara; 2002.

[2] Canım, Ridvan, Divan edebiyatında türler, Akçağ publications, (II Print), Ankara; 2011.

[3] Tekin, Talat, Orhon yazitları, Publications of Turkish language institution: 540, Ankara; 1988.

[4] Kurnaz, Cemal, Eski Türk edebiyatı, Berikan publications, Ankara; 2011.

[5] Haz. Arat, Reşit Rahmeti, Edib Ahmed B.Mahmud Yükneki, Atabetü'l-hakâyık,Publications of Turkish language institution, 142 Ankara; 2006.

[6] Haz. Arat, Reşit Rahmeti, Edib Ahmed B.Mahmud Yükneki, Atabetü'l-hakâyık,Publications of Turkish language institution, 142 Ankara; 2006

[7] Haz. Arat, Reşit Rahmeti, Edib Ahmed B.Mahmud Yükneki, Atabetü'l-hakâyık,Publications of Turkish language institution, 142 Ankara 2006.

[8] Köprülü, Fuat, Türk edebiyatında ilk mutasavvıflar, $2^{\text {nd }}$ print, Ankara; 1966.

[9] Eraslan, Kemal, Divan-1 hikmet, Seçmeler, Ministry of culture: 546, Ankara; 1991.

[10] Eraslan, Kemal, Divan-1 hikmet, Seçmeler, Ministry of culture: 546, Ankara; 1991.

[11] Tayşi, Mehmed Serhan, http://www.tded.org.tr//bpi.asp?caid $=354 \&$ cid $=1787 \&$ spec $=$ auth

[12] Kaplan, Prof. Dr. Mahmut, Hayriyye-i Nâbi, Publications of Atatürk culture centre: 350, Ankara; 2008.

[13] Beyzadeoğlu, Assist. Prof. Dr. Süreyya Ali, Sünbülzâde Vehbî, Lutfiyye, Cihan publications and printing, İstanbul; 1996.

[14] Ahmed Mürşidi Efendi, Pend-nâme, handwritten copy, 210 sht, on the shelf of a crafter in Burdur.

[15] Mermutlu, M.Sait (Haz), Pendnâme, Diyarbekirli Ahmed Mürşidî, Büyüyen Ay Publications, İstanbul 2012

[16] Akkuş, Metin, Klasik Türk şiirinin anlam dünyası; Edebî türler ve tarzlar, Fenomen Prints, Erzurum; 2007.

[17] Pala, İskender, Nasihatnâme, TDVİA the item in advisory book volume 32, p.410, İstanbul; 2006

1 This article is based on a report presented in 5th European Conference on Social Behavioral Sciences which was held on 11-14 September 2014, in St. Petersburg. 